\title{
ENTRE O ÉBANO E O MARFIM: IGUALDADE COMO RECONHECIMENTO E A HETEROIDENTIFICAÇÃO COMPLEMENTAR
}

\author{
BETWEEN EBONY AND IVORY: EQUALITY AS RECOGNITION AND RACIAL VERIFICATION \\ COMMISSSIONS
}

Gabrielle Oliveira Almeida ${ }^{1}$
Gustavo Hermont Corrêa ${ }^{2}$

\begin{abstract}
Resumo: o presente artigo objetiva investigar, sob o paradigma da igualdade como reconhecimento jurídico, se a práxis afeta à política de cotas raciais no Brasil se amolda à gramática moral dos conflitos sociais apresentada por Honneth (2003), a partir das experiências relacionadas às formas de reconhecimento, desrespeito e luta emancipatória. Pretendemos, igualmente, analisar se a utilização do procedimento de heteroidentificação complementar, com base exclusivamente no fenótipo dos candidatos, prescreve quadros interpretativos distintos para pardos e pretos: reconhecimento jurídico para estes e tensões morais para aqueles. A fim de se alcançar este escopo, são estudadas, nesta ordem, as dimensões do princípio da igualdade, a gramática proposta por Honneth (2003) e o status sociorracial do grupo dos pardos e pretos, a partir do processo histórico no qual se desenvolve a moderna política de cotas raciais. É adotado o método dedutivo. Concluímos que o procedimento de heteroidentificação complementar contemporâneo pode não se amoldar às percepções raciais do grupo dos pardos, conformando incipiente tensão moral hábil ao engendramento da luta por reconhecimento.
\end{abstract}

Palavras-chave: Cotas raciais. Igualdade. Pardos. Pretos. Reconhecimento.

\begin{abstract}
: this paper aims to investigate, under the paradigm of equality as recognition, whether praxis related to racial quotas policy in Brazil conforms to the moral grammar of social conflicts presented by Axel Honneth, from experiences related to forms of recognition, disrespect and emancipatory struggle. It is also intended to identify if the use of complementary heteroidentification procedure based on phenotype, only, prescribes different interpretative frameworks for browns and blacks: legal recognition for these and moral issues for those. In order to reach this scope, this article analyses the dimensions of the principle of equality, the grammar proposed by Honneth, and social and racial status of browns and blacks, starting from the historical process in which the modern policy of racial quotas is developed. It is used the deductive method. We concluded that the contemporary complementary heteroidentification procedure may not conform to racial perceptions adopted by the group of browns, forming an insipient moral tension capable of engendering the struggle for recognition. Keywords: Racial quotas. Equality. Browns. Blacks. Recognition.
\end{abstract}

Recebido em 24 de setembro de 2019 Avaliado em 8 de abril de 2020 (AVALIADOR A) Avaliado em 30 de abril de 2020 (AVALIADOR B)

Aceito em 30 de abril de 2020

\footnotetext{
1 Bacharel em Direito pelo Centro Universitário Newton Paiva; Estagiária de Pós-graduação na Defensoria Pública da União; Rua Pouso Alto, 15, Bairro Serra, Belo Horizonte, Minas Gerais; Brasil; https://orcid.org/0000-0002-9265-1542; almeidaogabrielle@gmail.com

2 Doutor em Direito Público pela Pontifícia Universidade Católica de Minas Gerais; Professor de Direito Constitucional II e III da Faculdade ASA de Brumadinho, de Teoria da Constituição e Direito Constitucional I e II do Centro Universitário Newton Paiva e de Direito Constitucional da Escola de Formação e Aperfeiçoamento de Sargentos da Polícia Militar do Estado de Minas Gerais; https://orcid.org/0000-0003-1702-7608; professorgustavocorrea@gmail.com
} 


\section{Introdução}

A utilização do sistema de cotas raciais nos procedimentos de acesso ao ensino superior público e aos quadros das carreiras do serviço público se apresenta como instrumento de correção da ausência de representatividade racial nessas instituições. É, por conseguinte, corolário da observância da norma programática alocada no art. $3^{\circ}$, I, da Constituição Federal de 1988, para a construção de uma sociedade livre, justa e solidária, a partir da consecução da fundamental garantia de igualdade, (i) em seu aspecto material e (ii) como reconhecimento.

Embora o critério exclusivamente autodeclaratório, de início adotado para facultar aos negros (pardos e pretos) a participação em processos seletivos, tenha sido estabelecido mediante estrita observância ao direito de autodeterminação, a práxis demonstrou, na breve experiência brasileira, o desvirtuamento do ideário de igualdade material. Multiplicaram-se, nos últimos anos, os casos de autodeclarações fraudulentas, que resultaram no acesso de sujeitos de fenotipia branca, portanto, não destinatários das cotas, às instituições públicas.

Analisada a questão pelo Supremo Tribunal Federal, decidiu a corte, em 2017, que a utilização de critérios subsidiários de heteroidentificação complementar de candidato pardo ou preto é legítima, a fim de que se garanta a efetividade da política de cotas raciais. Em observância ao princípio da autonomia das universidades, compete à cada instituição a regulamentação do procedimento de heteroidentificação. Já para o acesso aos serviços e empregos públicos em âmbito federal, embora prevista a reserva de vagas nos termos da Lei n. 12.990/2014, não há regulamentação do procedimento de heteroidentificação complementar.

Nesse sentido, o Ministério do Planejamento, Desenvolvimento e Gestão editou a Portaria Normativa n. 4, de 6 de abril de 2018 para disciplinar o procedimento de heteroidentificação complementar à autodeclaração dos candidatos pardos e pretos (BRASIL, 2018). A heteroidentificação sujeita os candidatos que se declararam pardos ou pretos à verificação da condição autodeclarada por comissão para este fim instituída. A comissão, composta por cinco membros, utilizará, exclusivamente, o critério fenotípico para aferição da condição declarada pelo candidato no concurso público.

Não se ignora que a adoção exclusiva do critério fenotípico pretende alcançar aqueles sujeitos posicionados no polo mais marginalizante do espectro discriminatório. Considerando que, no Brasil, o preconceito racial opera de acordo com as características físicas dos sujeitos, temos que o racismo à brasileira ${ }^{3}$ importa aumento do grau de exclusão social à medida que as características físicas dos indivíduos mais se aproximam da fenotipia negra.

\footnotetext{
3 Expressão utilizada por Oracy Nogueira em Preconceito de marca: as relações raciais em Itapetininga (1998), para denotar as diferentes manifestações do racismo no Brasil e nos Estados Unidos da América. Para o autor, em oposição ao caráter intergeracional da discriminação racial nos Estados Unidos, o racismo no Brasil opera, de forma preponderante, a partir do fenótipo dos sujeitos.
} 
As implicações práticas do estágio atual do procedimento de heteroidentificação complementar, agora como etapa formal dos certames públicos, trazem questões sobre o posicionamento de determinados sujeitos nos processos discursivos que orbitam em torno da reivindicação de sentidos para os semantemas pardo, preto e negro. Recorremos aqui à gramática moral dos conflitos sociais, proposta por Axel Honneth em Luta por Reconhecimento: a gramática moral dos conflitos sociais, de 2003, para apreender como isto ocorre para o grupo dos pardos.

Em se tratando da ambígua figura do pardo, quando a autodeclaração e a heteroclassificação se contradizem, o resultado é igualmente ambivalente: nos termos da gramática prescritiva de uma luta por reconhecimento, a heteroidentificação exsurge (i) tanto como reconhecimento jurídico para o subgrupo dos pretos (ii) quanto como tensão moral hábil a engendrar nova demanda por reconhecimento, desta vez, para o subgrupo dos pardos. Lembramos que a classificação oficial utilizada para fins de autodeclaração reúne pardos e pretos sob a categoria negros.

A partir da assunção de que a realidade é, essencialmente, discursiva, o trajeto da pesquisa compreende a análise das dimensões do conceito de igualdade, que, como reconhecimento, encontra arcabouço teórico nas noções de formas de reconhecimento, desrespeito e luta por reconhecimento. A seguir, demonstramos que a gramática moral dos conflitos sociais é vetor hábil à interpretação do sistema de cotas raciais e do procedimento de heteroidentificação complementar, para os quais observamos aquilo que nomeamos primeiro, segundo e terceiros movimentos, para descrever as sucessivas tensões morais que deram origem tanto a implementação das cotas quanto a adoção do procedimento de heteroidentificação complementar.

Após, retomamos os contextos sociodiscursivos que determinaram a inclusão e a manutenção do subgrupo dos pardos sob a categoria do grupo dos negros e, em seguida, analisamos a interação entre essas categorias e o estágio atual do procedimento de heteroidentificação complementar. Concluímos que, entre a autodeclaração e a heteroidentificação posterior, as percepções raciais que a pluralidade dos sujeitos incluídos sob o grupo dos pardos manifesta tende a divergir da heteroclassificação, o que contribui para o surgimento de possíveis tensões morais que podem dar origem à luta por reconhecimento.

\section{A reinvidicação do discurso}

A luta por emancipação é, sobretudo, uma luta por (re) significação. A atribuição de sentidos é a unidade sobre a qual a realidade é discursivamente construída e atravessada por contextos históricos que circunscrevem determinadas regras dos jogos de linguagem. Antecipando a prosa pela rima, Gilberto Freyre anuncia, ainda em 1926, "o outro Brasil que vem aí", ou a redenção 
pela mestiçagem. No Brasil de Freyre, "mais tropical, mais fraternal, mais brasileiro [...] as mulheres, em vez de cores boreais, terão as cores variamente tropicais." ${ }^{4}$

O mito fundador da democracia racial se constrói, assim, sob a prática discursiva em sua realidade material produtora de sentidos - e de realidades. Como pode o interlocutor dos anos dez deste século sequer supor "[...] as lutas, vitórias, ferimentos, dominações e servidões, através de tantas palavras cujo uso há tanto tempo reduziu as asperidades?" (FOUCAULT, 1996, p. 8).

Para falar sobre igualdade como reconhecimento, é necessário tropeçar nas asperidades do discurso a fim de se entender que, sob a doçura do leite coagulado e sob os chamegos safados, ocultam-se as violências tanto de raça quanto de gênero que atravessam o Brasil Colônia e chegam ao século XXI. Nesse sentido, a fim de realocar aqueles sujeitos expropriados de sua imputabilidade moral a integridade psíquica (HONNETH, 2003), reiteradamente eclipsada pela produção do discurso, é necessário assumir que o discurso não é simplesmente aquilo que "traduz as lutas ou os sistemas de dominação, mas aquilo por que, pelo que se luta, o poder do qual nos queremos apoderar." (FOUCAULT, 1996, p. 10).

É, assim, no campo da semântica que o direito à igualdade emerge em meio a um compartilhamento de significações e pertencimento a um determinado contexto ou mundo da vida (NIGRO, 2009, p. 191), investido de real possibilidade emancipatória, porque (re) significado a partir de discursos reivindicatórios, aos quais compete desvelar as assimetrias de poder inscritas nas relações sociais.

\section{Metodologia}

A pesquisa científica pressupõe a produção do conhecimento por meio da razão demonstrativa (logos). A investigação fundada no uso da razão objetiva diferenciar a opinião (doxa) do conhecimento científico (episteme). Quando o objeto de pesquisa está inscrito no campo do Direito, devemos assumir que o fenômeno jurídico é multívoco e, por isso, permeável aos influxos de outros campos epistêmicos, como a Filosofia e a Sociologia.

Entendemos que a pesquisa aqui proposta observa a interação entre o fenômeno social e o processo de nomogênese, sem olvidar que o Direito, ao mesmo tempo, é norma, é fato e é valor (REALE, 2003, p. 91). Perquirimos, então, como as interpretações atribuídas ao procedimento de heteroidentificação complementar se relacionam com o substrato axiológico no qual se inscreve o

\footnotetext{
$4 \quad$ Trata-se de trecho de uma das epígrafes da obra Casa Grande e Senzala. Neste caso um trecho de obra do próprio Gilberto Freyre, de 1926, o qual antecipa a perspectiva construída por este autor, a de um Brasil miscigenado. Vinte e dois anos após a 1ª edição de Casa Grande \& Senzala (1933), Carlos Drummond de Andrade escreve em 1955 A Gilberto Freyre. Seus versos evocam "[...] a linha negra do leite, coagulando-se em doçura." Antes disso, em Mafua de Malungo, publicado em 1948, Manuel Bandeira oferece Casa-grande \& senzala, para celebrar "[...] o grande livro que fala [...] dos chamegos safados de mulecas fulôs com sinhôs." Vale ressaltar que tanto Bandeira quanto Drummond foram utilizados como epígrafe em edições posteriores da obra de Freyre, como a utilizada para a pesquisa deste artigo. A tropicalidade apaziguadora, quase dócil, erige a igualdade pela qual ansiava Freyre: redimida pela miscigenação.
} 
princípio da igualdade. A hipótese aventada, a partir do marco teórico proposto por Axel Honneth, é de que a síntese da Luta por Reconhecimento encerra tese indicativa da emergência de um novo quadro de tensão moral.

Iteramos que a pesquisa aqui proposta é orientada pela noção de que a produção do conhecimento se traduz em probabilidade de verdade, por reconhecer que a utilização de uma determinada abordagem metodológica significa interpelar o problema de pesquisa com a finalidade de oferecer respostas, não necessariamente exaurientes. Adotamos, assim, o método dedutivo, cuja teoria de base é a gramática moral dos conflitos sociais descrita por Honneth, à luz da qual nos propomos a examinar a heteroidentificação complementar como objeto de pesquisa.

Sabendo que, em síntese, o método dedutivo parte de argumentos gerais para argumentos específicos (MEZZAROBA; MONTEIRO, 2009, p. 65), apresentamos como premissas gerais que (i) a expansão da eticidade de um grupo social compreende a relação entre sujeitos por meio de etapas de reconciliação e de conflito que se sucedem na linha do tempo, e que (ii) o conflito é impulsionado pelo surgimento de tensões morais ancoradas em experiências de desrespeito, ou ausência de reconhecimento.

As tensões identificadas no decurso dessa investigação descrevem o elastecimento da noção de igualdade, cujas dimensões formal e material parecem não mais oferecer resposta jurídicoinstitucional satisfatória às demandas de uma sociedade que se descobre racializada, não apesar da miscigenação, mas por causa dela. Assim, o modelo proposto pela gramática moral dos conflitos sociais a presenta um vetor interpretativo apto para analisar as particularidades da heteroidentificação complementar no contexto brasileiro.

\section{$3(\mathrm{Re})$ significando a noção de igualdade}

O processo de (re) significação da noção de igualdade percorre veredas de sentidos que consideram as representações dos indivíduos dentro do discurso jurídico. Para entender o paradigma da igualdade formal, toma-se o ser humano como unidade de racionalidade, da qual deriva, de forma coletiva, a organização de uma comunidade política. Dentro dessa comunidade a identidade comum partilhada repousa na cidadania, é dizer, naquela qualidade subjetiva reconhecida para alguns indivíduos, alocados na categoria de sujeitos de direito, abstratamente considerados, descritos não por aquilo que os distancia dos outros, mas por aquilo que os aproxima deles.

Assim, em nome de um princípio de igualdade, Moreira (2017), informado pelos pressupostos de generalidade e universalidade, afirma que: proteger os direitos da comunidade política significa rejeitar quaisquer privilégios injustos. Sob o prisma liberal, pressupõe-se que alcançar a igualdade jurídica, expressa na uniformização do tratamento jurídico entre as pessoas similarmente situadas, implica negar que as diferenças de status social podem ser juridicamente relevantes. 
Nesse sentido, quando dispôs a Constituição de 1891 que são eleitores os cidadãos maiores de 21 anos que se alistarem na forma da lei (BRASIL, 1891), não fora necessária a inclusão - ou mesmo exclusão - textual de negros ou mulheres no grupo dos cidadãos, porque a igualdade jurídica é tomada a partir de um grupo de sujeitos similarmente situados - homens brancos - e socialmente apreendidos em um aparente consenso político tácito.

Aparente porque o significado de igualdade que se desprende da Constituição de 1891 evidencia, nos termos propostos por Honneth (2003), a manutenção de práticas de desrespeito que atingem grupos historicamente excluídos da esfera de reconhecimento, ou não sujeitos de imputabilidade moral. O que o autor se propõe a investigar é justamente como a experiência de desrespeito está ancorada nas vivências afetivas dos sujeitos humanos, de modo que, motivando o conflito, reproduza a resistência social e, como consequência, a luta por reconhecimento.

Para exemplificar, trazemos o direito de sufrágio como dimensão do direito à igualdade para eleger representantes que, garantido aos brasileiros de um e de outro sexo (BRASIL, 1934), encontra guarida constitucional em 1934, como espécie de síntese da luta por reconhecimento travada a partir do alijamento histórico do grupo das mulheres da arena política. Esta síntese, contudo, vê-se inscrita em um processo dialógico e expansivo que prescreve a relação ética entre sujeitos por meio de etapas de reconciliação e de conflito que se sucedem na linha do tempo (HONNETH, 2003).

Não há, portanto, como falar em esvaziamento da luta por reconhecimento no campo do direito ao sufrágio, agora tomado como dimensão do direito à igualdade para ser eleito, porque as mulheres, embora correspondam a 51\% da população brasileira (IBGE, 2017b), permanecem ainda sub-representadas no parlamento pátrio. Note-se que para a legislatura 2019-2022, a cada 100 deputados federais, apenas 15 são mulheres (MONTESANTI, 2018). Se considerada a interseção entre gênero e raça, a sub-representação é ainda mais expressiva: a cada 100 deputados federais, 2,5 (duas e meia) são mulheres negras (ASSIS; FERRARI; LEÃO, 2018).

Se a práxis demonstrou que a igualdade formal não é suficiente para promover a emancipação da variedade de grupos de sujeitos, o paradigma da igualdade material só pode ser viabilizado a partir da (re) significação das representações dos indivíduos dentro do discurso jurídico: o sujeito de direito abstrato, cuja idealização se fundamenta em uma racionalidade unificadora, tem de ser agora considerado, segundo Moreira (2017), como ocupante de uma determinada posição em uma estrutura social, o que significa dizer que seu status jurídico não se pode distanciar das condições que produzem a realidade social.

A investigação do impacto das formas de exclusão sobre os indivíduos proposta por esse autor trava um diálogo com a noção de reconhecimento já sugerida por Hegel e retomada por Honneth: como se sabe reconhecido por um outro sujeito em algumas de suas capacidades e propriedades, o sujeito, contraposto ao outro, vem a conhecer partes de sua identidade única. $\mathrm{O}$ resultado do processo inter-relacional que culmina em reconhecimento partilhado manifesta, então, uma face voltada ao autoconhecimento. 
Ao admitir que a construção da individualidade espelha um processo intersubjetivo e, portanto, relacional, os membros de uma comunidade política começam, além de identificar aquilo no que se diferenciam uns dos outros, a reivindicar que as diferenças apreendidas não são moralmente relevantes para justificar as privações de direitos experienciadas, a despeito da pretensão normativa formal de igualdade.

Alcançar a dimensão material do direito à igualdade corresponde, então, a um processo de categorização do direito, por meio do qual a representação abstrata dos seres humanos é gradualmente abandonada em favor da consideração das diferenças que de fato existem entre os indivíduos. Assim, "o homem abstrato presente na doutrina liberal dá lugar ao homem situado dentro de relações sociais concretas, forma necessária para o conhecimento de sua vivência real." (MOREIRA, 2017, p. 61).

As formas de alijamento social, às quais Honneth (2003) denomina formas de desrespeito, radicam-se na ausência de reconhecimento. Desse modo, a pretensão de que a igualdade, como princípio jurídico, seja eficaz pressupõe a investigação, por meio das instituições, dos processos responsáveis por diferentes formas de discriminação. É com base nesse escrutínio que o princípio da igualdade pode se revestir de uma função transformadora da realidade social, impondo ao Estado a obrigação de programar políticas públicas que objetivem a inclusão social.

No entanto, se a dimensão material do direito à igualdade faz supor que a inclusão por meio do princípio da equidade, uma vez resolvida a questão da distribuição de oportunidades socioeconômicas, é suficiente para reparar as distorções históricas e sociais que mantêm determinados grupos relegados à subcidadania, a experiência contradiz esse argumento, ao mesmo tempo que descreve a luta por reconhecimento.

Retomando o exemplo anteriormente proposto, sabe-se que se o texto de 1934 garantiu proteção constitucional do direito ao voto feminino, a sub-representação das mulheres na política passa a ser enfrentada, sob o parâmetro da igualdade material, com a edição da Lei n. 9.100, de 29 de setembro de 1995 (BRASIL, 1995), ao prever que 20\%, no mínimo, das vagas de cada partido ou coligação deverão ser preenchidas por candidaturas de mulheres.

Entretanto, este enfrentamento no campo da legislação explicita que a distribuição numérica de oportunidades não guarda correspondência imediata com a dimensão do direito à igualdade como reconhecimento. Hoje, mais de dez anos após a edição da Lei n. 9.100, de 29 de setembro de 1995, e ainda sob a influência da recente alteração, via resolução do Tribunal Superior Eleitoral, que destinou 30\% dos recursos do Fundo Especial de Financiamento de Campanha às candidaturas femininas (COTA..., 2019), se as mulheres gozam (i) tanto do direito formal a serem votadas (ii) quanto de políticas distributivas que determinam a inclusão de candidatas, não são ainda reconhecidas como agentes igualmente competentes para atuar no campo político:

[...] Tem que ir pela vocação. Se os homens preferem mais política do que a mulher, tá certo, paciência, é a vocação. Se você fizer uma eleição para bailarinos e colocar uma cota de $50 \%$ para homens, você ia perder belíssimas bailarinas, 
porque a vocação da mulher para bailarina é muito maior do que a de homem. (MATTOSO; BRAGON, 2019).

A discriminação, entendida como forma de desrespeito sob a perspectiva de Honneth, pretende naturalizar a questão da desigualdade de gênero por meio da escolha lexical do semantema vocação, isto é, ao reduzir a aptidão à mera inclinação, o enunciador oculta o estado de coisas histórico e, portanto, sociocultural que opera desde tempos imemoriais para manter o grupo das mulheres excluído dos centros de tomada do poder. Essa estrutura impede a afirmação da cidadania porque "reproduz estigmas sociais responsáveis pela construção do outro como ser incapaz de atuar no espaço público de forma competente." (MOREIRA, 2017, p. 90).

Ora, não perceber e acolher a diversidade de contextos plurais que permeiam o mundo da vida que sustenta as bases da nossa infinitude humana é o mesmo que não atentar para o reconhecimento de si próprio, na medida em que não somos sem a presença do outro. Portanto, a reprodução de estigmas sociais discriminatórios sem uma reflexão acurada por vezes cega a percepção de que somos seres em constante transformação que precisam ser reconhecidos como parte integrante do aperfeiçoamento humano.

Lançamos até aqui algumas considerações iniciais sobre as noções de igualdade - como reconhecimento -, desrespeito, discriminação e luta por reconhecimento. Assumimos a existência de certo consenso que não mais nega que pessoas no Brasil são potencialmente discriminadas por questões afetas à raça e ao gênero, por exemplo. Recobramos, então, a centralidade da questão ora proposta, qual seja, se a eleição administrativa do procedimento de heteroidentificação complementar, pautado exclusivamente no critério fenotípico, guarda consigo o potencial para desvelar tensões morais hábeis a engendrar a luta por reconhecimento travada em torno dos sentidos de ser pardo no Brasil.

\section{A Gramática moral dos conflitos sociais}

Investigamos, a seguir, como as variadas formas de discriminação racial refletem as noções de reconhecimento, desrespeito e luta, integrantes da gramática moral dos conflitos proposta por Honneth (2003). Neste ponto, trazemos as contribuições de Fernandes (2018) acerca da dignidade da pessoa humana e da vedação a sua instrumentalização.

\subsection{0 que é reconhecimento}

Ao retomar o conteúdo da luta por reconhecimento proposto por Hegel, durante o período de Jena, ${ }^{5}$ Honneth (2003) volta sua atenção para uma nova dimensão do conflito social, relegado por

\footnotetext{
Descreve os anos de 1801 a 1806, quando Hegel lecionou na Universidade de Jena, na Alemanha. Neste período o autor desenvolve uma nova concepção sobre a relação entre filosofia e história.
} 
filósofos como Maquiavel e Hobbes ao campo da autopreservação individual. O contrato social deixa, para esse autor, de ser descrito como pacto que finda o estado precário de uma luta por sobrevivência de todos contra todos porque o estado de tensão social é condição interna, constitutivamente incluída no processo de expansão de uma eticidade que se viabiliza no conflito e por causa dele.

A ideia de conflito por si mesma é possível, apenas, porque pressupõe a existência de parceiros de interação que gozam de status de reconhecimento distintos: aqueles sujeitos, cujas pretensões de realização individual não se veem reconhecidas, deflagram um estado de tensão social que só se pode resolver por meio do enfrentamento travado na arena pública e que tende a certa forma de reconciliação. A esse processo corresponde a expansão da eticidade. Assim afirma Corrêa (2016, p. 68): "A responsabilidade ética não é só a racionalidade da tolerância: a ética tem que ser a racionalidade da solidariedade."

Essa expansão pode ser entendida, dessa maneira, como a possibilidade de realização da liberdade de todos os indivíduos em particular, em oposição àquelas práticas que percebem a vivência pública como necessariamente ancorada na restrição recíproca dos espaços de liberdade. Devemos observar que o exercício da liberdade ocorre em particular, o que significa dizer que os sujeitos são reconhecidos e considerados e, mais, fundamentalmente "[...] aprovados em sua natureza instintiva particular." (HONNETH, 2003, p. 80).

É a apreensão desta certeza de ser reconhecido a partir dos comportamentos praticados intersubjetivamente que permite a formação do sentimento de autoconfiança responsável por capacitar os indivíduos para a participação da formação política da vontade. Neste ponto, vislumbrase a convergência entre imputação moral e imputação jurídica, à medida que a esfera do ser-reconhecido só é mantida em vida pela nova constituição dos indivíduos em pessoas de direito.

Opera-se, dessa forma, o que Moreira (2017) identifica como transposição da concepção de homem no discurso filosófico para o discurso jurídico, no qual o significado de sujeito de direito designa o status dos indivíduos dentro de uma comunidade política, que os reconhece, por sua vez, como sujeitos detentores de direitos e também como indivíduos passíveis de imputação jurídica.

\subsection{Três formas de reconhecimento}

Agora que sabemos que o reconhecimento compreende as condições materiais para a expansão da eticidade, se quisermos alcançar a questão do desrespeito, devemos, antes, examinar as condições de constituição do sujeito enquanto indivíduo. Neste ponto, Honneth (2003) recorre - e atualiza - a psicologia social de George Herbert Mead (1863-1931), para delinear três maneiras de reconhecimento.

autor identifica as seguintes esferas de reconhecimento: (i) o amor, (ii) o direito e (iii) a solidariedade. Em todas elas o que se observa é o processo intersubjetivo de individuação, sempre relacionado ao pressuposto de uma "[...] ampliação simultânea das relações de reconhecimento 
mútuo." (HONNETH, 2003, p. 156). Embora nos interesse, em particular, as esferas do direito e da solidariedade, a interação entre estes três campos nos impele a discorrer brevemente sobre a noção do amor como forma de reconhecimento.

A primeira esfera corresponde ao início da vida infantil, período no qual mãe e bebê interagem em uma relação de codependência - tanto biológica quanto psíquica. Neste momento, Honneth está interessado em investigar as consequências do fim da fase de intersubjetividade indiferenciada, ou simbiose, da qual emergem, segundo o autor, dois indivíduos inéditos e distintos. É esta primeira experiência intersubjetiva de amor, se bem-sucedida, que constituirá o pressuposto psíquico da autoconfiança individual, imprescindível para a participação autossuficiente na vida pública.

A esfera do reconhecimento jurídico, por seu turno, descreve a condição de imputabilidade moral ínsita à existência humana, isto é, o Direito pressupõe que todos os sujeitos são moralmente imputáveis, porque irmanados por uma característica essencial: a humanidade. Aqui o indivíduo ultrapassa o domínio particular das relações sociais próximas para se estabelecer como sujeito pertencente a uma comunidade política.

O processo de individualização se dará, então, de modo intersubjetivo, a partir do reconhecimento mútuo das pretensões de cada sujeito-de-direito como legítimas. Nesse sentido, o sujeito adulto obtém a possibilidade de conceber sua ação como verdadeira manifestação da própria autonomia, respeitada por todos os outros, mediante a experiência do reconhecimento jurídico. Se nas relações primárias de amor e amizade o indivíduo desenvolve o que Honneth chama de autoconfiança, o reconhecimento jurídico introduz um componente de valoração própria identificado com o autorrespeito.

A terceira e última forma de reconhecimento está relacionada à estima da qual gozam os indivíduos no seio da sociedade. $\bigcirc$ respeito social se alicerça naquelas capacidades e características que são reconhecidas como valorosas para toda a comunidade social, de modo que o processo de individuação descrito por esta esfera permite que um indivíduo possa experienciar a si mesmo em um processo intersubjetivo de edificação da própria autoestima.

Vimos até aqui que o reconhecimento se produz e reproduz em três esferas distintas, não obstante interrelacionadas, que permitem aos sujeitos o desenvolvimento intersubjetivo de características associadas (i) à autoconfiança, (ii) ao autorrespeito e (iii) à autoestima. Posto isso, para imaginarmos o conteúdo semântico da luta por reconhecimento temos de obrigatoriamente indagar sobre as formas e expressões do desrespeito hábeis à mobilização das tensões intrassociais.

\subsection{0 desrespeito e a luta por reconhecimento}

As três formas de reconhecimento correspondem a três tipos de desrespeito que, se experenciados, podem servir de motivação ao surgimento de conflitos sociais descritivos da luta por reconhecimento. $\bigcirc$ desrespeito é descrito pelo autor como forma de reconhecimento recusado, 
ou seja, qualquer prática lesiva que atinja os processos de individualização proscritos pelas esferas do amor, do direito e da solidariedade. A lesão a esses processos significa que as "[...] pessoas são feridas numa compreensão positiva de si mesmas, que elas adquiriram de maneira intersubjetiva." (HONNETH, 2003, p. 213).

Honneth considera que nem Hegel nem Mead ofereceram uma resposta satisfatória à questão do desrespeito como motivação para o impulso que projeta a resistência social, o conflito e a luta por reconhecimento. Para responder este problema, o autor identifica três práticas ofensivas que operam nas distintas esferas de reconhecimento, são elas: (i) os maus-tratos, ou violação, (ii) a privação de direitos e (iii) a degradação.

Os maus-tratos reúnem as práticas que retiram do ser humano todas as possibilidades de livre disposição de seu próprio corpo, representando a espécie mais elementar de rebaixamento pessoal. A violação não se limita à dor física, porque adentra o campo do inconsciente para estabelecer uma relação de sujeição entre dois ou mais indivíduos. Uma vez nulificada a possibilidade de individuação por meio do amor e da apreensão autônoma do corpo, fere-se a autoconfiança e rebaixa-se o indivíduo a qualquer coisa menos humana e, portanto, menos digna de respeito que seus pares.

Lembramos neste item que os corpos negros, como também os corpos femininos, estiveram, por muito tempo, juridicamente postos à mercê de seus senhores. Fossem eles proprietários, cônjuges ou pais, remanesciam isentos das penas pecuniárias prescritas pelo Título XXXVI, do Livro $\mathrm{V}$ das Ordenações Filipinas, em virtude da aplicação de castigos corporais: "[...] estas penas não haverão lugar [...] em quem castigar criado, ou discípulo ou sua mulher ou seu filho ou seu escravo." (ORDENAÇÕES FILIPINAS, 2019). ${ }^{6}$

A segunda forma de ofensa, ou desrespeito como privação de direitos, é descrita pelo autor como a prática de quaisquer experiências de rebaixamento que afetam o autorrespeito moral dos indivíduos, o que significa dizer que os sujeitos são estruturalmente excluídos da posse de determinados direitos no interior de uma sociedade. Honneth (2003) aloca a percepção dessa privação em um processo de mudança histórica que permite, àqueles que se veem desrespeitados, apreender um compromisso formal de garantia da imputabilidade moral compartilhada que, todavia, não se cumpre em termos práticos ou materiais.

Isso porque, para o autor, o grau de universalização de determinados direitos não satisfaz a demanda por reconhecimento se não for possível garantir, no mínimo, o alcance material dos direitos institucionalmente garantidos. Este status material, por seu turno, é forjado no bojo do desenvolvimento das relações jurídicas, responsáveis por elastecer o conteúdo semântico que redefine o sujeito moralmente imputável.

Nesse sentido, entendemos que a garantia formal de isonomia para realização de certames públicos - concursos vestibulares e provimento de vagas em cargos públicos - não foi suficiente para

6 O Livro V dessa compilação jurídica disciplinou o Direito Penal português no Brasil Colônia até o ano de 1831. 
impedir a manutenção da baixa representatividade de grupos vulneráveis, como aquele formado por pardos e pretos, nas instituições públicas. As ações afirmativas - como espécie de síntese da luta por reconhecimento, como veremos adiante - apresentam-se como via jurídica de afastamento "[...] do ideal de tratamento simétrico para alcançar um objetivo estatal legítimo, que é a eliminação da marginalização social." (MOREIRA, 2017, p. 18).

A terceira forma de desrespeito ameaça diretamente a autoestima, edificada por meio das relações subjetivas que conformam a estima social. Se dentro da tessitura social subsistem modos de hierarquia que valorizam determinadas tradições culturais em detrimento de outras formas de vida e de projetos pessoais de autorrealização, tidas como de menor valor ou deficientes, nota-se a perpetuação do desrespeito sistemático, traduzido aqui como degradação.

Este tipo de ofensa atinge, em maior ou menor grau, todos aqueles grupos desviantes não normativos - o que no caso brasileiro admite componentes variados como classe, procedência regional, orientação sexual, raça, gênero etc. Daí dizermos que as propriedades específicas desses grupos cristalizam formas de vida que, desprovidas de estima social, afetam a possibilidade de estes indivíduos entenderem a si mesmos como seres apreciados por suas peculiaridades e capacidades características.

Acrescentamos que, embora aparentemente alheias ao campo do reconhecimento jurídico descrito por Honneth, as formas de desrespeito próprias à esfera da solidariedade social também se revestem de antijuridicidade, quando analisadas sob o princípio da dignidade humana como vetor interpretativo. A supressão da estima social alcança direitos fundamentais autônomos e nãohierárquicos, a exemplo do direito à vida, em sua dimensão psicossocial, à integridade psíquica e à honra subjetiva.

A fim de subtrair o caráter amplo e abstrato, comumente atribuído ao princípio da dignidade humana, para garantir-lhe exequibilidade normativa, Fernandes (2018, p. 424) propõe parâmetros mínimos ${ }^{7}$ de verificação da observância do meta-princípio. Segundo estes critérios, se uma determinada situação fática é, em alguma medida, maculada por (i) instrumentalização da vida humana, (ii) lesão à autonomia existencial, (iii) desrespeito ao mínimo existencial ou (iv) ausência de reconhecimento, estamos diante de um quadro de violação à dignidade da pessoa humana.

Postos à prova na esfera da solidariedade social, esses critérios informam a existência de um consenso moral sobre a posição de determinados sujeitos no seio da sociedade, independentemente da análise sobre a existência de reconhecimento jurídico. Para ilustrar esta premissa, tratemos do grupo das mulheres negras, considerando, para isso, a justaposição de dois eixos discriminatórios: 0 preconceito de gênero e o preconceito de raça.

\footnotetext{
Para o autor, a instrumentalização acontece quando o ser humano é visto como meio para atingir um determinado fim, o que implica desumanizá-lo, reduzi-lo à coisa. A autonomia existencial diz respeito à faculdade de cada ser humano titularizar seus projetos pessoais de vida. $\bigcirc$ mínimo existencial, como critério, corresponde à manutenção de condições materiais mínimas para a vida e o reconhecimento pressupõe o respeito às identidades particulares.
} 
Em Casa Grande \& Senzala, Freyre recupera o adágio registrado pelo historiador alemão H. Handelman, em 1931, para sintetizar o comportamento sexual do brasileiro. O ditado "branca para casar, mulata para f..., [sic] negra para trabalhar" (FREYRE, 2003, p. 72) revela que os lugares sociais destinados às mulheres variam de acordo com a cor da pele. $O$ discurso da mestiçagem dócil, afastada da violência de gênero, confinou a mulher mulata e negra de pele clara a um único lócus possível de realização social, ainda que cravada de ambiguidades: o da mulata exuberante, geralmente seminua, a serviço do deleite estético masculino, como demonstram as sucessivas - e padronizadas - edições da Globeleza. ${ }^{8}$

A edição de 2013, no entanto, atualiza o adágio registrado por Handelman, oitenta anos antes. Nayara Justino, a primeira mulher negra de pele escura escolhida para encarnar a Globeleza, é substituída naquele mesmo ano, após reação racista do público, por Érika Moura, negra de pele clara (THE GUARDIAN, 2019). A conduta omissiva da emissora Globo deixa patente a instrumentalização dos corpos das mulheres negras - de pele clara e de pele escura - quando, destacada de seu papel de concessionária de serviço de telecomunicações, opta por contribuir para a manutenção do estereótipo da mulata hipersexualizada e da negra trabalhadora.

Para falar sobre lesão da autonomia existencial, apontamos os dados sobre mortalidade materna trazidos pelo Sistema de Informações de Mortalidade, do Ministério da Saúde, segundo o qual 60\% das mães que vieram a óbito em 2012 eram negras. A cientista social Carolina Montiel complementa que gestantes pardas e pretas recebem tratamento desigual, quando comparadas às brancas, porque na área da saúde subsiste a noção de que a mulher negra é mais forte e mais resistente à dor (AS FACES DA VIOLÊNCIA OBSTÉTRICA, 2019).

A violação aos direitos reprodutivos e de planejamento familiar das mulheres negras no âmbito da consecução do direito à saúde denota que, a despeito da garantia formal de tratamento igualitário durante a assistência integral à saúde, na prática, prevalece o tratamento racializado, ancorado em estereótipos que remetem à resistência dos corpos femininos negros à escravidão.

A violação ao mínimo existencial não pode, igualmente, ser analisada descolada de um recorte convergente entre gênero e raça. Não obstante a proteção legal inscrita na Consolidação das Leis do Trabalho, que garante aos trabalhadores salário igual, sem distinção de sexo, a mulher negra é remunerada cerca de $60 \%$ menos que o homem branco. É o que deduz o resultado da pesquisa Retrato das desigualdades de gênero e raça - 20 anos, do Instituto de Pesquisa Econômica Aplicada (Ipea) publicada em 2015 (INSTITUTO DE PESQUISA ECONÔMICA APLICADA, 2015).

A despeito da proteção jurídica, esta reiterada prática salarial denuncia que a sociedade brasileira encara o trabalho da mulher e, em especial, o trabalho da mulher negra, como desprovido de valor, o que pode indicar que, no campo da solidariedade, do inconsciente coletivo, a mão de obra feminina e negra ainda guarda relação com o trabalho escravo.

\footnotetext{
8 Nome dado à mulher negra que samba durante as vinhetas de carnaval da TV Globo.
} 
Por fim, exemplo da ausência de reconhecimento no campo da solidariedade social é trazido em números pela campanha Cadê Nossa Boneca? [sic], promovida pela organização nãogovernamental soteropolitana Avante. Após levantamento de mercado, a ONG denunciou que, apesar de o grupo de pardos e pretos ultrapassar metade da população nacional (IBGE, 2017a), apenas $3 \%$ das bonecas infantis para venda online são negras (TERTO, 2016). A baixa representatividade imposta pela lógica de mercado induz à naturalização da desvalorização das características fenotípicas negras, especialmente as femininas, ainda durante a infância.

Os exemplos acima sugerem um apanhado de questões cotidianas, todas associadas ao livre desenvolvimento da personalidade, mormente subestimadas por aqueles que gozam de um status de cidadania condizente com o Estado Democrático de Direito. De outro giro, oferecem panorama sobre como a ausência de reconhecimento no campo da solidariedade social implica, em último caso, violação ao direito à vida digna na medida em que a sonegação da estima representa, igualmente, a denegação de um modelo humano de existência psíquica concreta e realizável, para lembrarmos os termos utilizados por Neusa Santos Souza em Tornar-se Negro (SOUZA, 1983).

Apreendidos os significados inscritos nos conceitos de reconhecimento e desrespeito, entendemos que o compartilhamento das experiências de não-reconhecimento individualmente vividas serve à motivação para a luta por reconhecimento, em lugar da luta por autoafirmação. Isso porque a individualização só pode ser lida como intersubjetiva e, portanto, relacional.

A luta por reconhecimento faz supor então um caráter moral e não necessariamente identitário, por não se buscar o reconhecimento das identidades em particular, mas sim a alocação individual da imputabilidade moral de que goza cada sujeito em uma comunidade política. Assim, para Honneth (2003), uma busca por emancipação social e jurídica de grupos alijados pressupõe uma ação provocadora para levar o outro indivíduo - e seus muitos associados - a respeitar o que não foi ainda reconhecido pelas formas de relacionamento. Organizada em coletivo ou de modo individual, a provocação é este movimento que acusa o reconhecimento denegado.

Maria Carolina de Jesus provoca ao dizer, em 1960, com Quarto de Despejo, que celebra o treze de maio - abolição da escravidão - "lutando contra a escravatura atual - a fome!" (JESUS, 2007, p. 32). Também os movimentos negros da alvorada do século XXI provocam, ao demandarem por ações afirmativas, e continuam a provocar, nos dias atuais, por políticas públicas que combatam as fraudes nos sistemas de cotas e promovam real emancipação daqueles sujeitos localizados ao polo do espectro fenotípico que determina a marginalização social.

As motivações, objeto do questionamento de Honneth, emergem da solidariedade negada, da forja intersubjetiva da estima social turvada por experiências de desrespeito, e, assim, "[...] não isentas de dor" (HONNETH, 2003, p. 211), da decrescente tolerância ao subprivilégio jurídico que conduz a um sentimento paralisante de vergonha social, do qual só o protesto ativo e a resistência podem levar a uma pressão intrassocial para o estabelecimento prático e político de instituições garantidoras da liberdade. 
Sob essa perspectiva, Moreira (2017) defende que a existência dos direitos fundamentais só é possível dentro de uma sociedade informada pela igualdade política e jurídica, compartilhada por todos os seus componentes. Há aqui uma aproximação com a perspectiva de Honneth, para quem os efeitos jurídicos da luta por reconhecimento evidenciam a emergência também de uma pressão normativa, consequente da demanda social por ampliação de direitos, que resulta em desenvolvimento do Direito.

A reivindicação por significados socialmente partilhados não esvazia, todavia, a luta por reconhecimento. $O$ elastecimento das pretensões intersubjetivas vem, mormente, acompanhado de novas tensões morais que voltam a impelir para além da respectiva medida institucionalizada de progresso social. Este processo, dinâmico, por natureza, sugere a repetição do conflito, o que pressupõe a concomitância de avanços e contradições, forjados no processo histórico e social.

\section{Cotas raciais na gramática moral dos conflitos sociais}

A discriminação sistemática e consequente marginalização dos grupos sociais corporificam a experiência de desrespeito hábil à motivação da luta pelo reconhecimento. A partir da teoria de Honneth, Gonçalves (2017, p. 268) reconhece que "[...] o direito e suas instâncias formais teriam um papel extremamente importante em captar esses pleitos sociais e 'devolvê-los' à sociedade na forma de um 'reconhecimento oficial'", ou seja, institucional.

Neste contexto, as ações afirmativas, aqui entendidas como "o conjunto de estratégias [...] que visam a favorecer [...] segmentos sociais encontrados em piores condições de competição no meio social, em razão [...] da prática de discriminações negativas" (MENEZES, 2001, p.21 apud LIMA, 2012, p. 161) insurgem como resposta jurídico-institucional à histórica discriminação enfrentada pela população parda e preta brasileira.

Isso se deve ao que Moreira (2017) denomina como função transformadora do princípio da igualdade, que impõe ao Estado a obrigação de criar políticas públicas fomentadoras da inclusão de grupos sociais. Esta "dimensão emancipatória do conceito de igualdade" (MOREIRA, 2017, p. 19), cuja pretensão é eliminar padrões de exclusão social, fundamenta a exposição de motivos do Projeto de Lei n. 6.738/2007, que deu origem à Lei n. 12.990/2014, vejamos:

[...] ainda que os concursos públicos constituam método de seleção isonômico, meritocrático e transparente, sua mera utilização não tem sido suficiente para garantir um tratamento isonômico entre as raças, falhando em fomentar o resgate de dívida histórica que o Brasil mantém com a população negra. (BRASIL, 2014).

Embora o critério exclusivamente autodeclaratório, inicialmente adotado para facultar aos pardos e negros a participação em processos seletivos, tenha sido estabelecido mediante estrita observância ao direito de autodeterminação, a práxis demonstrou, na breve experiência brasileira, 
incontinente desvirtuamento do ideário de igualdade integrativa, a partir da multiplicação de casos de autodeclarações falsas, identificadas como fraudes ao sistema de cotas raciais, realidade documentada (BRASIL, 2017) e acompanhada pela sociedade e pelo judiciário.

O argumento comumente apresentado para justificar a utilização de cotas raciais por candidatos não pardos ou não pretos evocava, muitas vezes, tanto a impossibilidade de se determinar, com base em meios científicos, brasileiros não-mestiços, quanto a ascendência negra imediata, o que justificaria, segundo essas premissas, a estruturação da identidade desses sujeitos em volta das questões afetas à vivência negra.

Moreira (2017) esclarece que este raciocínio está radicado na ideia de que vivemos, no Brasil, em uma democracia racial engendrada pela naturalização da mestiçagem, apreendida pelo senso comum como mera celebração do encontro entre três raças - indígena, branca e negra - e despojada, por isso, de pretensões políticas. Ao refutar este argumento, o autor desvela um projeto racial que satisfaz, ainda hoje, os anseios de uma elite político-econômica para manutenção de seus privilégios.

A eleição da miscigenação como projeto de poder é denotada por Southey (1977), para quem a mestiçagem desempenhou um papel civilizador e neutralizador de conflitos sociais. Igualmente, Tadei (2002) argumenta que, entre o final do século XVIII e o início do século XIX, a miscigenação adquiriu contornos de solução epistemológica à ameaça de revoltas por parte dos escravizados. Aduz o autor que, durante o século XIX, a ascensão das teorias bioantropológicas que se seguiram ao darwinismo social serviram de base à implementação de políticas públicas claramente discriminatórias - legitimadoras dos discursos sobre os problemas raciais do Brasil.

Como exemplo, lembramos que ao fim do regime escravocrata seguiu-se a política de imigração europeia, para cumprir uma função dupla: (i) resolver o problema da mão de obra, já que vicejava a crença na inaptidão da população negra para o trabalho livre, e (ii) promover a melhoria racial da população brasileira, ou seja, embranquecê-la.

Para descrever o conjunto de práticas que envolveram este projeto de poder subsumido à ideia de constituição de uma identidade nacional, Tadei retoma a noção de dispositivo proposta por Foucault. Alerta assim para a existência de um novo campo de racionalidade no qual um conjunto de saberes e estratégias de poder se fazem incidir sobre a identidade nacional, via discursos, ações, leis e programas institucionais, com a finalidade de "[...] criar uma consistência entre todos esses elementos díspares, gerando subjetividades dóceis, mal delimitadas e manipuláveis." (TADEI, 2002, p. 3).

Atentamos, uma vez mais, para a relevância dos percursos discursivos como formas de construção da realidade social. Repensar o conteúdo do semantema miscigenação implica abandonar a suposição da confraternização das raças, como queria Freyre, para entrever um projeto de poder erigido sobre uma narrativa de silenciamento das violências perpetradas com a chancela do Estado.

A difusão do mito da democracia racial enquanto prática discursiva favorece o compartilhamento de uma racionalidade que oculta padrões sistêmicos de exclusão social de base 
fenotípica, ancorado essencialmente em um aparente paroxismo que nada diz sobre como opera a discriminação em função da raça: se somos todos mestiços, somos todos negros, brancos e indígenas, logo, somos todos iguais.

A força deste discurso compartilhado, enraizado em uma matriz cognitiva que informa a realidade material produtora de sentidos, é tal, que ele opera à revelia do enunciador. Vejamos o voto do Ministro Luis Barroso no julgamento da ADC n. 41:

No Brasil, é certo, nunca houve um conflito racial aberto ou uma segregação formal. O racismo nesses trópicos é velado, dissimulado, encoberto pelo mito da democracia racial e pela cordialidade do brasileiro. Não é, porém, difícil constatar a sua presença na realidade brasileira. Apesar de o país ser altamente miscigenado, a convivência entre brancos e negros se dá majoritariamente em relações hierarquizadas, de subordinação e subalternidade. (BRASIL, 2017, p. 42, grifo nosso).

Se é certo que o voto do Ministro atribui à democracia racial o seu devido caráter mitológico, o emprego do advérbio concessivo "apesar de" evidencia uma quebra de expectativa, é dizer, no entender do enunciador a miscigenação pressuporia uma convivência entre iguais, que, entretanto, não se confirma. Uma argumentação que assumisse que o vocábulo miscigenação comporta a expressão de um projeto racial de poder incorporaria não uma concessão, mas uma explicação. Assim, as relações hierarquizadas entre brancos e negros não se dariam apesar da miscigenação, mas por causa dela.

A dissociação entre a preponderância de relações assimétricas de poder marcadas pela raça e a crença em uma identidade nacional mestiça sugere a existência de uma tolerância entre grupos raciais, responsável pela representação do Brasil como uma sociedade comprometida com o tratamento igualitário. Deriva daí a ideia de que a sociedade brasileira rejeita a discriminação social. Esta representação fica evidente a partir dos resultados apresentados pela pesquisa Skol Diálogos, realizada pelo IBOPE, no ano de 2017. A análise dos dados explicitou que, embora 83\% dos entrevistados tenham se declarado não-preconceituosos, $72 \%$ já fizeram algum comentário ofensivo (71\% DA..., 2017).

A aparente incoerência entre o que se enuncia e o que se pratica - inexiste intenção de discriminar, mas, ao mesmo tempo, há adesão comunicativa à expressões como "Mulher tem que se dar ao respeito" e "Não sou preconceituoso, até tenho um amigo negro" - é sintetizada pelo que Bonilla-Silva, citado por Moreira, identifica como "[...] construção de uma sociedade racista na qual não há racistas." (BONILLA-SILVA, 1997, p. 465 apud MOREIRA, 2017, p. 137). Isso porque, segundo o autor, "[...] a cultura condena as formas de discriminação, mas a estrutura de exclusão atua indiferentemente da vontade individual." (MOREIRA, 2017, p. 138).

As tensões morais que irrompem no cerne da discussão sobre a eleição única do critério autodeclarativo admitem como premissa a noção de que pessoas brancas, ao invocarem a mestiçagem 
para exercer direitos tradicionalmente renegados às populações pardas e pretas, produzem uma experiência de desrespeito. Essa experiência é percebida pelos grupos excluídos como subterfúgio tendente à manutenção dos privilégios historicamente assegurados àquelas elites raciais brancas.

Assim, as experiências de reconhecimento social e jurídicos denegados ${ }^{9}$ motivam a, essencialmente dialógica, luta por reconhecimento que, materializada a partir da mobilização de movimentos negros e sob o amparo doutrinário do direito antidiscriminatório, promove uma pressão intrassocial para o estabelecimento prático de instituições garantidoras da liberdade. Neste cenário, o Supremo Tribunal Federal, provocado pelo ajuizamento da ADC n. 41, firmou a tese de que é legítima a utilização de critérios subsidiários de heteroidentificação (BRASIL, 2017).

Em voto que acompanhou a posição do Ministro Barroso, a Ministra Rosa Weber recobra a argumentação já apresentada quando do julgamento da Ação de Descumprimento de Preceito Fundamental n. 186. Na ocasião, a decisão plenária prestigiou o arcabouço teórico desenvolvido por Nogueira (2007) e analisado por Cavalcanti (2009), para quem a "concepção de branco e não branco varia de indivíduo para indivíduo dentro do mesmo grupo ou da mesma família, e atua - insidioso e abominável como qualquer forma de discriminação -, mediante a preterição." (CAVALCANTI, 2009 apud BRASIL, 2017, p. 115).

A análise da autora se constrói com fundamento na tese de Nogueira, que já na década de 1950 estabelecia uma distinção entre o que o autor denominou preconceito de origem, característico nos Estados Unidos da América, em oposição ao preconceito de marca, prática prescritiva no Brasil. O que distingue estes dois modos de exclusão é que, enquanto nos Estados Unidos o critério de discriminação prevalente é a ascendência - one drop rule ${ }^{10}$-, no Brasil o preconceito é praticado com base no fenótipo, ou aparência racial, consideradas não só as gradações da cor como também as características fisionômicas.

Entender a discriminação racial no contexto brasileiro como "[...] a submissão de determinado grupo a tratamento desvantajoso justificado por um julgamento moral negativo [...]" (MOREIRA, 2017, p. 27), atribuído em função de características fenotípicas, implica, então, uma premissa bivalente. Se, por um lado, o preconceito de marca deslegitima os discursos sobre a existência de uma democracia racial possibilitada pela miscigenação, por outro serve de fundamento à análise dos traços fisionômicos dos candidatos como meio constitucionalmente adequado para distinguir negros e não negros.

A luta por reconhecimento, cujo primeiro movimento resultou na adoção de política de cotas, é novamente mobilizada, a partir de experiências de desrespeito, desta vez com o objetivo de

\footnotetext{
9 Reconhecimento jurídico de duas formas: a um porque o critério autodeclaratório não satisfaz à garantia dos direitos tutelados pela lei de cotas, haja vista as tentativas de fraudes ao sistema, e a dois porque o Judiciário, alienado de um conteúdo antidiscriminatório, considerou, por diversas vezes, o critério autodeclarativo constitucional, até a ADC n. 41 encerrar a discussão sobre o assunto.

10 A regra da "uma gota de sangue". A Suprema Corte norte-americana atribui juridicidade ao preconceito de origem em 1896, em Plessy Contra Ferguson.
} 
ampliar de forma material o sentido dos direitos institucionalizados por meio do procedimento de heteroidentificação complementar. Trazemos aqui como exemplo a edição da Portaria Normativa n. 4, de 6 de abril de 2018, editada em âmbito federal para regulamentar o procedimento de heteroidentificação complementar como etapa formal da realização de concursos públicos (BRASIL, 2018).

As condições discursivas - próprias do jogo democrático - que antecederam a edição da Portaria Normativa n. 4, de 6 de abril de 2018 foram engendradas dentro de um espectro participativo que contemplou, além da consulta eletrônica realizada entre junho e julho de 2017, o seminário $A$ Política de Cotas no Serviço Público: avanços e desafios, em setembro de 2017 (ANDRADE, 2018). Essas iniciativas, lideradas por Grupo de Trabalho Interministerial, propuseram a revisão e o a primoramento da Orientação Normativa n. 3, de 1 de agosto de 2016 e contemplaram a participação tanto de entidades institucionais quanto de organizações civis, como a Educafro e o Instituto de Advocacia Racial e Ambiental (IARA).

A atuação dos movimentos sociais, nos dizeres de Honneth (2003, p. 258), explicita a existência "[...] de uma semântica coletiva que permite interpretar as experiências de desapontamento pessoal como algo que afeta não só o eu individual, mas também um círculo de muitos outros sujeitos." Chamamos de segundo movimento esta experiência de desrespeito coletivamente partilhada e motivadora das tensões morais subjacentes às novas demandas sociais que provocaram o Supremo Tribunal Federal a declarar, em 2017, a constitucionalidade do procedimento de heteroidentificação complementar.

Assim, a utilização exclusiva do critério fenotípico para aferição da condição declarada por candidato em concurso público, prescrita pela Portaria Normativa n. 4, de 6 de abril de 2018 (BRASIL, 2018), nos termos do item 3.3 e 3.5.1 do relatório final do Grupo de Trabalho Interministerial (BRASIL, 2017), confirma o teor do art. $2^{\circ}, \mathbb{S} 1^{\circ}$ da Orientação Normativa n. 3 , de 1 de agosto de 2016 (BRASIL, 2016). A eleição do critério exclusivamente fenotípico, ao pôr termo à utilização do argumento da democracia racial - e da miscigenação -, satisfaz momentaneamente o conteúdo da luta por reconhecimento.

Dizemos isso porque o modelo previsto por Honneth antevê, com fundamento na variedade das experiências de desrespeito, "[...] a busca coletiva por relações ampliadas de reconhecimento." (HONNETH, 2003, p. 257). A síntese proscrita, então, por uma determinada forma de reconhecimento logo cede lugar a outras demandas, que insuflam a potência de um novo conflito tendente a elastecer o estado de liberdade comunicativamente vivido e compartilhado.

A insurgência destas tensões morais pode indicar que as ações institucionais incumbidas de garantir reconhecimento jurídico para um grupo historicamente vulnerável em função da cor pardos e pretos reunidos em volta da semântica proposta pelos movimentos negros como elemento unificador e central de um projeto político identitário - podem terminar por desestabilizar, em algum grau, o ideário da identidade negra por meio de espécie de negação à identidade parda. 
Deparamo-nos, neste momento, com um contexto fático que em nada se confunde com as autodeclarações fraudulentas, cujas justificativas apelaram ao mito da democracia racial para evocar a ascendência e a identidade negra como fundamentos justificadores da condição negra, a despeito do evidente fenótipo branco. Se o advento da heteroclassificação desestimulou - e tende a afastar em definitivo - a utilização das cotas de ingresso por candidatos fenotipicamente brancos, nova disputa semântica começa a gravitar em torno dos sentidos do que significa ser negro, pardo e preto.

Note-se que a discussão em torno da constitucionalidade da heteroidentificação complementar retoma o texto do parágrafo único, art. 2º da Lei n. 12.990/2014 (BRASIL, 2014), que previu a heteroclassificação como medida administrativa cabível em caso de fraude na autodeclaração. Firmou-se em princípio o entendimento de que apenas a fraude, ou uso de meio ardiloso com o intuito de contornar a lei (VENOSA, 2011, p. 2013), poderia elidir a presunção de validade da autodeclaração, atraindo, assim, a abertura de procedimento administrativo de verificação da declaração prestada.

Por este motivo, muitos editais de certames públicos promoveram a reserva de vagas e a apuração administrativa, em caso de fraude, deixando de estabelecer de plano, todavia, o procedimento de heteroidentificação como etapa formal do concurso, o que atraiu o controle de legalidade dos atos administrativos pelo Judiciário. Caso que ilustra esta situação teve origem no concurso realizado em 2015, pelo Instituto Rio Branco, vinculado ao Ministério das Relações Exteriores, para compor os quadros da diplomacia brasileira.

Após denúncia, L.N.S (BRASIL, 2016) foi submetido à comissão para verificação, não prevista em edital, que não confirmou sua declaração como pardo. Excluído do certame, o candidato ajuizou ação no bojo da qual o juízo de origem entendeu que a inexistência em edital da previsão de etapa de heteroidentificação complementar maculava o ato administrativo de exclusão do candidato, por inobservância ao princípio da legalidade. Apesar de a decisão garantir ao candidato participação no curso de formação para terceiro secretário, cargo inicial da carreira, L.N.S não foi aprovado nessa fase.

Em situação semelhante, o Tribunal de Justiça da Bahia (BAHIA, 2017) admitiu a inclusão posterior ao edital do procedimento de heteroidentificação, por entender que a previsão editalícia de verificação ulterior, em caso de falsidade na declaração, era condição suficiente à instalação de comissão de verificação. Denunciada, M.M.A, candidata ao cargo de procuradora do Município de Salvador, autodeclarada parda, submeteu-se à verificação, que não confirmou sua autodeclaração. Embora excluída das cotas, o TJBA franqueou à candidata permanecer no certame no regime de ampla concorrência, sob fundamento de ausência de intenção fraudulenta.

Circunstância distinta - e peculiar - das acima descritas atraiu recentemente a análise do Judiciário. Trata-se de publicação de editais que previram como fase formal de seus respectivos certames a etapa de heteroidentificação complementar. Formadas as bancas, a instituição realizadora do concurso procedeu à exclusão de candidatos não considerados pardos. J.J.S (DISTRITO FEDERAL, 2018), participante de processo seletivo para ocupar cargo público na Fundação de Previdência 
Complementar do Servidor Público Federal (Funpresp - EXE), foi excluído do certame após ser submetido à heteroidentificação complementar.

O juízo de origem considerou o ato legal, ao fundamento de que a não verificação da condição negra por parte da banca, de forma unânime, foi suficiente para a eliminação do candidato. A sentença foi reformada em 2018, pelo Tribunal de Justiça do Distrito Federal e Territórios (TJDFT), em decorrência de fato superveniente nos termos do art. 933 do Código de Processo Civil: após prolação da sentença, o recorrente foi considerado pardo, por banca da mesma realizadora do concurso da Funpresp - EXE, também incumbida da realização dos certames: (i) do Superior Tribunal de Justiça e (ii) do Superior Tribunal Militar, ambos em 2018.

Já L.M.O (AMAZONAS, 2018), candidato ao cargo de Analista do Ministério Público da União, via certame realizado após a edição da Portaria Normativa n. 4, de 6 de abril de 2018 do Ministério do Planejamento Desenvolvimento e Gestão, foi afastado do concurso após ter se submetido ao procedimento de heteroidentificação complementar. Depois de recorrer à Justiça Federal, teve garantido em sede de tutela de urgência seu direito a compor a lista dos cotistas aprovados, por entender o juízo que não era razoável admitir a mudança da condição racial do autor em curto interregno temporal. Isso porque o candidato já havia sido considerado pardo por banca de heteroclassificação da mesma realizadora do certame, naquele mesmo ano, durante as etapas do concurso promovido pelo Tribunal Regional Federal da 1ª Região - TRF1.

Todos os casos aqui trazidos apresentam em comum a contradição entre a autodeclaração dos indivíduos como pardos, em contraponto à heteroclassificação como não-pardos. Verônica Daflon, em tese apresentada à Universidade Estadual do Rio de Janeiro - UERJ - em 2014, indica que este não é um fenômeno isolado, e para isso oferece análise de Luisa Schwartzman, em artigo publicado na Journal of Latin American Studies, pela Universidade de Cambridge.

Schwartzman (apud DAFLON, 2014), ao investigar a implementação das cotas raciais na UERJ, conclui que as interpretações dos indivíduos a respeito das categorias de classificação de cor ou raça divergem das classificações delineadas pelos idealizadores das políticas de ação afirmativa. Para tentar elucidar a controvérsia, recobramos a posição do Presidente da Comissão de Concurso para Procurador do Munícipio de Salvador e do Procurador Geral do Município de Salvador, no mandado de segurança impetrado por M.M.A:

É preciso ter em mente que, afora os indivíduos de cor preta, só fazem jus a ações afirmativas tais o cidadão cujo tom de pele pardo constitua um padrão fenotípico que se possa identificar, com segurança, como sendo efetivamente pertencente à fatia populacional sujeita ao preconceito de origem étnico-racial: é preciso ter cor e aparência própria do grupo social discriminado e, por isso mesmo, sujeito a uma atmosfera social de vulnerabilidade e hipossuficiência multidimensionais. (BAHIA 2017, p. 18, grifo nosso). 
O argumento é que a vulnerabilidade experienciada em função do fenótipo não encontra correspondência imediata com o não pertencimento dos indivíduos ao grupo dos brancos. Vimos que a discriminação racial no Brasil opera mecanismos de exclusão com base no conjunto das características físicas dos sujeitos. É a leitura fenotípica a predominantemente responsável pela alocação intersubjetiva de determinados indivíduos nas categorias prescritivas identificadas como brancos e negros.

Desse modo, é apenas lógico supor uma escala de marginalização variável em função do fenótipo. Significa dizer que quanto mais as características de um determinado sujeito o posicionam próximo dos indivíduos socialmente lidos como brancos, menor o grau de marginalização. Em contrapartida, quanto mais as características físicas o aproximam do grupo dos negros, maior o grau de marginalização. A este fenômeno dá-se o nome de pigmentocracia, ou colorismo, "uma das faces do racismo na qual sujeitos com diferentes tons de pele são tratados de acordo com os sentidos sociais que revestem seus grupos étnicos." (WALKER, 1982 apud FERREIRA; CAMINHA, 2017, p. 157).

Daí a defesa de que o objetivo das comissões reside justamente na identificação dos quadros fenotípicos que, enquanto "presença política deixada no corpo sob a forma de uma disposição biológica" (FERREIRA; CAMINHA, 2017, p. 157) correspondam às mais variadas formas de discriminação racial e, por conseguinte, de marginalização social. Por este motivo a fenotipia é apreendida como "[...] a única métrica possível. [...] São os traços fenotípicos que induzem à discriminação e apreensão dos valores raciais construídos na sociedade brasileira." (ANDRADE, 2018). Assim, às comissões incumbe (i) identificar os negros (e não os não brancos) como (ii) não permitir que brancos sejam destinatários da política.

A sucessão de eventos que vimos até aqui permite-nos observar a dimensão interpretativa da luta por reconhecimento, isto é, para além de descrever as tensões que se nutrem no seio das relações sociais, a perspectiva temporal inaugura a noção de processo histórico, cuja síntese termina em ampliação do significado de reconhecimento. Nesse sentido, perquirimos se o procedimento de heteroclassificação com utilização exclusiva do critério fenotípico pode motivar o surgimento de tensões morais, até então ignoradas, em decorrência do impacto do procedimento sobre os autoidentificados como pardos.

\section{Entre o ébano e o marfim}

Como enunciamos anteriormente, o discurso é aquilo posto no centro do embate por significados. A luta por reconhecimento, engendrada nos processos sociopolíticos e institucionais de justificação e implementação das cotas raciais, é também uma luta pela (re)semantização dos conceitos de igualdade, raça, cor e privilégio. Dito isso, se quisermos entender a pluralidade de demandas por reconhecimento, bem como de que maneira elas se relacionam com o espectro da 
fenotipia parda e preta e, por conseguinte, com os processos discriminatórios que incidem sobre estas categorias, precisamos, antes, situar, discursivamente, esses dois grupos.

Guimarães (2008 apud DAFLON, 2014) sintetiza uma espécie de projeto racial que se formou, com o advento da década de 1960, a partir do rechaço ao mito da democracia racial. A ancoragem em ideologias afrocentradas resultou no afastamento de categorias de cor intermediárias, como pardo, mulato e moreno em favor da dicotomia branco-negro. Aquelas categorias seriam, assim, assimiladas por essa última, como forma de valorização e positivação do grupo negro, ressignificado para contemplar todos os descendentes de africanos.

A mestiçagem - e as categorias cromáticas que ela traz consigo - é então associada à promoção da diluição da identidade negra, de forma tanto a negar a negritude quanto a aquiescer ao ideal de branquidade, em um movimento que desvelaria a ausência de consciência racial. A narrativa eleita para promover a consolidação da identidade negra, demanda, por isso, a abolição das categorias intermediárias de cor - moreno, mestiço, mulato -, vistas como eufemismos denegatórios do ser-negro.

Desse modo, a reunião de pardos e pretos sob a categoria negros serve à pedagogia política cujo objetivo é "[...] elevar a consciência acerca do preconceito racial e denunciar a ideologia velada e racista do branqueamento." (DAFLON, 2014, p. 43). Para além da questão identitária, a autora explica que o agrupamento encontra justificativa na uniformidade de características socioeconômicas entre pretos e pardos, cujas semelhanças, registradas com métodos estatísticos desde a década de 1970, justificaram a reunião desses dois grupos sob a meta-categoria não-brancos, para fins de análise estatística.

Sob essa perspectiva, o sistema de classificações raciais proposto pelo Instituto Brasileiro de Geografia e Estatística (IBGE) é resultado da dinâmica das relações raciais no Brasil e corresponde em grande medida às reflexões sugeridas pela pluralidade do movimento negro para promover a valorização da população negra. De igual modo, Osório (2003 apud DAFLON, 2014) defende que a classificação tripartite por cor - brancos, pardos e pretos - é a mais técnica quando comparada com o registro de respostas espontâneas, de cujo conjunto o termo moreno é um dos mais escolhidos.

A exclusão desse termo da classificação por cor está fundamentada em critérios sóciohistóricos, políticos e identitários, pois seu emprego revelaria um mecanismo de escape ao racismo apenas possível àquele sujeito cujas características físicas permitem que ele transite entre o grupo dos brancos e o grupo dos negros. Assim, o caráter estrutural do racismo no Brasil, responsável por perpetuar privilégios para o grupo dos brancos, compele o moreno, o mestiço, a assumir a identidade racial que corresponda ao maior número de vantagens globalmente consideradas.

Para combater esta lógica, os termos levantados a partir do emprego das classificações espontâneas, como moreno, bege e mulato, subsumem-se, então, à subcategoria parda, que em conjunto com a subcategoria preta compõe o grupo dos negros. Para o propósito das ações afirmativas, Osório (2003, p. 24 apud DAFLON, 2014, p. 54) aponta a coerência em reunir os dois subgrupos, porque, quando comparados aos brancos, a situação de desigualdade na qual se encontram pardos e 
pretos tem a mesma origem racial, o que os posiciona como beneficiários legítimos de quaisquer ações que venham a ser tomadas no sentido de reverter o quadro histórico e vigente dessas desigualdades.

Se por um lado os pardos, tomados como grupo, são destinatários viáveis de políticas públicas de redistribuição e de reconhecimento, por outro, vão-se alijando das ações afirmativas que preveem a utilização do procedimento de heteroclassificação. Como exemplo, citamos o procedimento complementar de heteroidentificação racial promovido pela primeira vez no concurso vestibular da Universidade Federal de Minas Gerais (UFMG).

Dos 965 inscritos para ocupar as vagas destinadas à cota racial, 842 compareceram ao registro acadêmico, sendo que 276 tiveram a matrícula indeferida após submissão à comissão de heteroidentificação complementar (CANDIDATOS..., 2018). O número impressiona por corresponder a mais de $30 \%$ de todos os candidatos autodeclarados pardos ou pretos. $O$ advento da heteroclassificação faz supor, desse modo, que os candidatos sabiam que suas características físicas seriam avaliadas por terceiros, mas, ainda assim, autoidentificaram-se como pardos. Os efeitos dessa imprecisão foram antecipados por Becker (2017, p. 23), para quem:

[...] independentemente de sua ascendência genética, aqueles que não ostentam fenótipo negro ou, reversamente, ostentam fenótipo branco, restam como que "imunes" às discriminações que costumam cercar o fenótipo negro num contexto em que vige o "preconceito de marca", a importar na conclusão de que dificilmente terão sofrido perda de oportunidades sociais associadas à condição negra que justifiquem acesso privilegiado a vaga em instituição federal de ensino superior ou cargo público por meio de ação afirmativa voltada exatamente a igualar os desfavorecidos em razão de condição fenotípica que não ostentam.

Com efeito, o racismo à brasileira opera sob o paradigma do preconceito de marca, o que significa dizer que aqueles indivíduos identificados como pretos ocupam o polo mais marginalizante do espectro da discriminação. A apreensão desse espectro é importante porque permite inferir que pardos e pretos não são submetidos à discriminação da mesma forma, o que sinaliza que esses dois subgrupos carecem de modos distintos de reconhecimento jurídico.

Utilizando-se da técnica de razão de chances - odds of rattio -, Daflon (2014, p. 89) apresenta dados sobre a percepção da discriminação por sujeitos em diferentes posições do espectro racial. De acordo com esta metodologia, (i) os pardos têm 1,4 vezes mais chances de já terem se sentido discriminados que os morenos e 2 vezes mais chances de já terem se sentido discriminados que os brancos. Já (ii) os pretos têm 4 vezes mais chances de já terem se sentido discriminados que os pardos e quase 9 vezes mais chances de já terem se sentido discriminados que os brancos.

Os resultados acima confirmam, no campo da percepção da discriminação, o que já justificava, desde a década de 1970, o agrupamento das subcategorias pardos e pretos sob a categoria negros: na esfera socioeconômica os pardos passam por processos discriminatórios semelhantes àqueles enfrentados pelos pretos, a exemplo da inserção no mercado de trabalho e no sistema 
educacional. São, todavia, segundo a autora, menos discriminados em suas relações interpessoais, tais como as relações de amizade e casamento.

Ainda, assim, é persistente a subnotificação da discriminação racial entre os pardos, que apresentam índices de percepção da discriminação consideravelmente mais baixos do que os indivíduos autoclassificados como pretos. Para tentar explicar este fenômeno perceptual, Daflon (2014, p. 101) aponta algumas hipóteses, quais sejam: o caráter binário do racismo, a linguagem, também binária, do antirracismo e a fixação do ideário da mestiçagem. São indícios explicativos da baixa percepção:

1. o possível caráter binário do racismo manifesto (negro versus branco), que faria com que os indivíduos portadores de outras identidades que não a negra encontrassem dificuldade de acomodar suas experiências com a discriminação dentro do seu repertório identitário; 2. a possibilidade não concorrente de que a linguagem do antirracismo seja também binária, em especial em razão do "novo projeto racial" propugnado pelos movimentos sociais negros e abraçado pelo Estado. [...] Tais discursos contribuiriam assim para cultivar entre os individuos a ideia de que as discriminações raciais atingem unicamente os negros, o que pode levar a uma subnotificação da discriminação contra outros grupos; 3 . a possibilidade de que os ideários da "morenidade" e "mestiçagem" sejam elementos constitutivos da autoimagem positiva de parte significativa dos brasileiros; [...] e que implicam uma determinada visão acerca da natureza das desigualdades e discriminações que obstaculiza a interpretação dos preconceitos como de natureza racial. (DAFLON, 2014, p. 101).

A baixa percepção da discriminação também explicita o caráter ambivalente da representação social do pardo na sociedade brasileira. A disposição de características fenotípicas tanto brancas quanto negras aloca o pardo em uma posição que historicamente sempre the sugeriu a aproximação ao grupo dos brancos, como possibilidade de fuga do racismo, estratégia inacessível aos negros. O reconhecimento jurídico por meio do acesso às cotas inaugura espécie de vantagem material, sugerindo-lhe, pela primeira vez, a aproximação ao grupo dos negros desassociada da experiência da dor pela cor.

O que a atual experiência das bancas de heteroclassificação sinaliza, entretanto, é que a reunião de pardos e pretos sob o mesmo grupo não necessariamente assimila as suas diferenças, o que pode significar que políticas públicas direcionadas igualmente a estes dois subgrupos podem negligenciar a realidade sociorracial efetivamente apreendida por cada um deles. Nesse sentido:

É surpresa para muitos a inclusão do "pardo" ao lado do "preto" como beneficiário das políticas públicas de ação afirmativa, tais como as cotas no ensino superior e concursos públicos. A discriminação racial contra os pardos é ignorada ou negada por boa parte dos brasileiros e, portanto, parece ilógico dedicar-lhes esforços específicos de promoção socioeconômica. [...] A complexidade das classificações de cor é também mobilizada com frequência como argumento para descaracterizar particularmente esse grupo como beneficiário legítimo de políticas de promoção de igualdade. (DAFLON, 2014, p. 67). 
O ideal destinatário da cota racial parece ser aquele sujeito cuja cor do corpo indica o trespasse de sua existência pelas mais variadas formas de exclusão. Este processo marginalizante contempla, dentre as categorias discriminatórias propostas por Moreira (2017), desde a discriminação direta, a exemplo do tratamento arbitrário dispensado aos sujeitos em função da cor (CRIANÇAS..., 2019), até a discriminação estrutural, entendida como a soma de todas as desvantagens sociais, que é responsável por manter um grupo em situação permanente de subordinação (SILVA, 2018).

Já os pardos, não identificados de imediato como um grupo discriminado racialmente, embora mormente pareçam não se submeter à discriminação direta, estão sujeitos a outras formas de exclusão, mais sutis, a exemplo da manutenção do privilégio enquanto mecanismo de exclusão. $\bigcirc$ privilégio como modalidade de discriminação opera com o fim de manter as vantagens sociais nas mãos de grupos dominantes, o que é curiosamente percebido por esse grupo como prerrogativa em relação ao acesso a diversas formas de oportunidades sociais.

A recente experiência das bancas de heteroidentificação vem indicando a existência de um grupo não identificado como branco. Afastado, logo, da parcela que ostenta o privilégio enquanto veículo de opressão de minorias. Esse mesmo grupo, autodeclarado pardo, não congrega características fenotípicas marcadas por uma marginalização racial radical, o que legitima sua exclusão como destinatário da política de cotas, ao mesmo tempo em que lhe denega o reconhecimento jurídico. Eis o limbo do pardo.

Em resposta à nossa proposta inicial, parece-nos evidente que o atual status da política de cotas no Brasil delineia um quadro interpretativo acerca do paradigma da igualdade como reconhecimento, por conferir à diferença tratamento emancipatório, nos termos da ADC n. 41 (BRASIL, 2017). Por outro lado, entendemos que a regulamentação do procedimento de heteroidentificação complementar, ao se pautar no critério exclusivamente fenotípico, tende a excluir aqueles autodeclarados pardos, que não se identificam com o grupo dos brancos, nem tampouco consolidam uma identidade negra.

É latente aqui a possibilidade de tensão moral identitária insurgente fundada em aspecto racial que, se mobilizada como nova demanda de parte da sociedade, pode engendrar a luta por reconhecimento e contribuir para o elastecimento da eticidade socialmente compartilhada por negros e não-negros, indicando a iminência de um terceiro movimento, em direção a uma resposta jurídico-institucional que desafia o Estado, sob o paradigma da igualdade como reconhecimento, a mobilizar o Direito como expressão jurídica de respeito aos grupos vulneráveis e de tratamento emancipatório da diferença.

Por fim, assumimos que a recorrência da contradição entre a autodeclaração e a heteroidentificação dentro do grupo dos pardos, lócus de ambiguidade política e identitária, aponta para uma espécie de denegação do reconhecimento jurídico, o que, por seu turno, pode indicar a necessidade de adequar as políticas públicas ao funcionamento peculiar do racismo no Brasil, 
porque é neste não lugar do pardo que viceja a potência de uma tensão moral indutiva da luta por reconhecimento.

\section{Conclusão}

Vimos que a moderna acepção do princípio da igualdade contempla uma dimensão emancipatória da qual emerge o reconhecimento tanto como (i) forma de posicionar um determinado sujeito, destinatário de efetivas condições materiais e imateriais de existência, dentro de um conjunto social, quanto como (ii) meio de apreensão de um quadro interpretativo dos conflitos sociais, porque trespassado por processos sócio-históricos.

O reconhecimento é o que permite o desenvolvimento do ethos de uma comunidade política a partir do partilhamento intersubjetivo de relações recíprocas de estima, nas esferas afetiva, jurídica e social. O desrespeito, por seu turno, corresponde à ausência de reconhecimento em qualquer dessas esferas, o que, se identificado como ofensa a todo um grupo, extrapolando, assim, os limites da individualidade, sugere a eclosão de tensões morais.

Traduzidas em conflitos sociais, essas tensões habilitam a luta por reconhecimento, processo que induz, inexoravelmente, ao elastecimento das relações intersubjetivas para acomodar as novas semânticas atribuídas ao sentido de igualdade, agora ampliadas sob o paradigma da inclusão social. Esse processo, porque permeado de historicidade, é dinâmico e dialógico, o que significa dizer que o alcance de uma subsequente etapa de reconciliação do ethos, por meio do reconhecimento, exige, necessariamente, que essa mesma etapa mobilize o surgimento de outras tensões morais.

No âmbito das ações afirmativas, percorremos três movimentos de síntese da luta por reconhecimento. $\bigcirc$ primeiro corresponde à adoção da política de cotas raciais para estabelecer reserva de vagas para negros (pardos e pretos) em certames destinados ao ingresso em universidades e cargos públicos. A implementação das cotas conforma resposta institucional à demanda da população negra para atribuir materialidade ao sentido de igualdade.

O segundo diz respeito à recente declaração de constitucionalidade, pelo STF, do procedimento de heteroidentificação complementar, como forma de impedir a fraude, intentada por brancos, ao sistema de cotas. Notamos que, nos termos da gramática proposta por Honneth, a fraude ilustra experiência de ofensa ao grupo racialmente vulnerável.

O terceiro e incipiente movimento, que se delineia na medida em que sujeitos efetivamente autoidentificados como pardos são heteroclassificados de forma diversa pelas bancas examinadoras dos certames, aponta para o surgimento de um questionamento acerca das categorias de cor institucionalmente adotadas. Parece-nos, assim, que o não-lugar do pardo é circunstância hábil ao surgimento de novas tensões morais, o que pode indicar a necessidade de adequação das políticas públicas ao peculiar mecanismo do racismo no Brasil. 
A materialização do direito à diferença pressupõe a realização de uma comunidade política para além do paradigma da tolerância. Para isso, o Estado Democrático de Direito assume função contramajoritária de albergar e traduzir, em termos jurídicos, as demandas sociais daqueles grupos historicamente alijados dos espaços políticos - e discursivos - de construção da realidade social. A expressão jurídica deste reconhecimento retoma, assim, o consenso de que a consecução da isonomia material, ao impor não apenas a proibição do tratamento excludente mas também a obrigação de incluir, justifica a opção política por instituir desigualdades de direito como instrumentos para alcance da igualdade de fato.

\section{Referências}

AMAZONAS. Tribunal Regional Federal da 1ª Região. Ação ordinária 1005799-15.2018.4.01.3200. Juíza Jaiza Maria Pinto Fraxe. 2018.

ANDRADE, Allyne. O novo processo de verificação da autodeclaração étnico-racial nos concursos federais. Justificando, São Paulo, 12 abr. 2018. Disponível em: http://www.justificando. com/2018/04/12/o-novo-processo-de-verificacao-da-autodeclaracao-etnico-racial-nos-concursos-federais/. Acesso em: 13 set. 2019.

AS FACES DA VIOLÊNCIA OBSTÉTRICA. Disponível em: https://www.ufrgs.br/jordi/172-violenciaobstetrica/violencia-obstetrica/. Acesso em: 13 set. 2019.

ASSIS, Carolina de; FERRARI, Marília; LEÃO, Natalia. Câmara dos deputados terá menos homens brancos e mais mulheres brancas, negras e $1^{\mathrm{a}}$ indígena em 2019. Gênero e número, [S. 1.], 8 out. 2018. Disponível em: http://www.generonumero.media/camara-dos-deputados-tera-mais-mulheres-brancas-negras-e-indigena-e-menos-homens-brancos-em-2019/. Acesso em: 12 set. 2019.

BAHIA. Tribunal de Justiça da Bahia. Mandado de Segurança. 0015114-08.2016.8.05.0000. Relator: Desembargador José Edivaldo Rocha Rotondano. 2017.

BECKER, Anelise. Cotas raciais: problematicidade prática da definição de seus beneficiários. Boletim Científico ESMPU, Brasília, DF, ano 16, n. 49, p. 15-48, jan./jun. 2017.

BRASIL. Constituição da República dos Estados Unidos do Brasil. Rio de Janeiro, 1891.

BRASIL. Constituição da República dos Estados Unidos do Brasil. Rio de Janeiro, 1934.

BRASIL. Lei n. 9.100, de 29 de setembro de 1995. Estabelece normas para a realização das eleições municipais de 3 de outubro de 1996, e dá outras providências. Diário Oficial da União, Brasília, DF, 2 out. 1995.

BRASIL. Lei 12.990, de 9 de junho de 2014. Reserva aos negros 20\% (vinte por cento) das vagas oferecidas nos concursos públicos para provimento de cargos efetivos e empregos públicos no âmbito da administração pública federal, das autarquias, das fundações públicas, das empresas públicas e das sociedades de economia mista controladas pela União. Diário Oficial da União, Brasília, DF, 10 jun. 2014. 
BRASIL. Supremo Tribunal Federal. Ação Declaratória de Constitucionalidade n. 41. Ministro: Relator Roberto Barroso, Diário da Justiça Eletrônico, 8 jun. 2017.

BRASIL. Ministério do Planejamento, Desenvolvimento e Gestão. Secretaria de Gestão de Pessoas. Portaria Normativa n. 4, de 6 de abril de 2018. Regulamenta o procedimento de heteroidentificação complementar à autodeclaração dos candidatos negros, para fins de preenchimento das vagas reservadas nos concursos públicos federais, nos termos da Lei n. 12.990, de 9 de junho de 2014. Diário Oficial da União, Brasília, DF, 7 abr. 2018.

BRASIL. Orientação Normativa n. 3, de 1 de agosto de 2016. Dispõe sobre regras de aferição da veracidade da autodeclaração prestada por candidatos negros para fins do disposto na Lei $\mathrm{n}^{\circ} 12.990$, de 9 de junho de 2014. Diário Oficial da União, Brasília, DF, 2 ago. 2016.

CANDIDATOS SERÃO ATENDIDOS POR NOVA COMISSÃO DE HETEROIDENTIFICAÇÃO. UFMG, 8 mar. 2018. Disponível em: https://ufmg.br/comunicacao/noticias/candidatos-serao-atendidos-por-nova-comissao-de-heteroidentificacao. Acesso em: 13 set. 2019.

CAVALCANTI. Maria Laura Viveiros de Castro. Estigma e relações raciais na obra pioneira de Oracy Nogueira. In: BOTELHO, André; SCHWARCZ, Lilia Moritz. Um enigma chamado Brasil: 29 intérpretes e um país. São Paulo: Companhia das Letras, 2009.

CORRÊA, Gustavo Hermont. O Ministério Público Sobre o Olhar do Outro: Uma Experiência Fundada na Alteridade de Emmanuel Levinas. Rio de Janeiro: Lumen Juris, 2016.

COTA DE 30\% PARA MULHERES NAS ELEIÇÕES PROPORCIONAIS DEVERÁ SER CUMPRIDA POR CADA PARTIDO EM 2020. Tribunal Superior Eleitoral, 8 mar. 2019. Disponível em: http:// www.tse.jus.br/imprensa/noticias-tse/2019/Marco/cota-de-30-para-mulheres-nas-eleicoes-proporcionais-devera-ser-cumprida-por-cada-partido-em-2020. Acesso em: 12 set. 2019.

CRIANÇAS DE ESCOLA PÚBLICA SÃO BARRADAS EM SHOPPING DE SÃO PAULO. Folha de São Paulo, São Paulo, 21 mar. 2019. Disponível em: https://www1.folha.uol.com.br/cotidiano/2019/03/criancas-de-escola-publica-sao-barradas-em-shopping-de-sao-paulo.shtml. Acesso em: 13 set. 2019.

DAFLON, Verônica Tostes. Tão longe, tão perto: pretos e pardos e o enigma racial brasileiro. 2014. Tese (Doutorado em Sociologia) - Instituto de Estudos Sociais e Políticos, Universidade do Estado do Rio de Janeiro, Rio de Janeiro, 2014.

71\% DA POPULAÇÃO DA REGIÃO SUL ASSUME QUE JÁ FEZ ALGUM COMENTÁRIO PRECONCEITUOSO. Ibope Inteligência, 18 out. 2017. Disponível em: http://www.ibopeinteligencia. $\mathrm{com} /$ noticias-e-pesquisas/71-da-populacao-da-regiao-sul-assume-que-ja-fez-algum-comentario-preconceituoso/. Acesso em: 13 set. 2019.

DISTRITO FEDERAL. Tribunal De Justiça Do Distrito Federal E Territórios. Apelação cível n. 0034032-03.2016.8.07.0001. Relator: Desembargador Roberto Freitas. 2018.

FERNANDES, Bernardo Gonçalves. Curso de Direito Constitucional. 10. ed. Salvador: JusPODIVM, 2018. 
FERREIRA, Dina Maria Martins; CAMINHA, Tibério. Pigmentocracia e a Experiência do Preterimento na Homossexualidade Negra. Cadernos de Linguagem e Sociedade. Distrito Federal: Universidade de Brasília, 2017. Disponível em: http://periodicos.unb.br/index.php/les/article/view/5796. Acesso em: 13 set. 2019.

FOUCAULT, Michel. A Ordem do Discurso. São Paulo: Loyola, 1996.

FREYRE, Gilberto. Casa Grande \& Senzala: formação da família brasileira sobre o regime da família patriarcal. 48. ed. São Paulo: Global, 2003.

GONÇALVES, Ricardo Juozepavicius. Direito Em Axel Honneth: A Luta Por Reconhecimento em Desenvolvimento. Revista Direito e Liberdade - RDL - ESMARN, [S. l.], v. 19, n. 2, p. 253-275, maio/ ago. 2017.

HONNETH, Axel. Luta por Reconhecimento: a gramática moral dos conflitos sociais. São Paulo: Editora 34, 2003.

IBGE. População chega a 205,5 milhões, com menos brancos e mais pardos e pretos. Agência de Notícias do IBGE, 2017a. Disponível em: https://agenciadenoticias.ibge.gov.br/agencia-noticias/2012-agencia-de-noticias/noticias/18282-populacao-chega-a-205-5-milhoes-com-menos-brancos-e-mais-pardos-e-pretos. Acesso em: 13 set. 2019.

IBGE. Porcentagem da População por Sexo. Pesquisa Nacional por Amostra de Domicílios Contínua. Rio de Janeiro: IBGE, $2017 b$.

INSTITUTO DE PESQUISA ECONÔMICA E APLICADA. Rendimento médio mensal no trabalho principal da população ocupada de 16 anos ou mais de idade, por sexo e cor/raça-Brasil, 1995 a 2015. 2015. Disponível em: http://www.ipea.gov.br/portal/images/stories/PDFs/170306_apresentacao_ retrato.pdf. Acesso em: 13 set. 2019.

JESUS, Maria Carolina de. Quarto de despejo: diário de uma favelada. 9. ed. São Paulo: Ática, 2007.

LIMA, Rogério. Medeiros Garcia de. As cotas raciais e o Supremo Tribunal Federal. Revista Eletrônica de Direito do Centro Universitário Newton Paiva, Belo Horizonte, n. 18, 2012.

MATTOSO, Camila; BRAGON, Ranier. Política não é muito da mulher, diz presidente nacional do PSL. Folha de São Paulo, São Paulo, 10 fev. 2019. Disponível em: https://www1.folha.uol.com.br/ poder/2019/02/politica-nao-e-muito-da-mulher-diz-presidente-nacional-do-psl.shtml. Acesso em: 12 set. 2019.

MEZZAROBA, Orides; MONTEIRO, Cláudia Servilha. Manual de Metodologia da Pesquisa no Direito. 5. ed. rev. e atual. São Paulo: Saraiva, 2009.

MONTESANTI, Beatriz. Mulheres são 15\% do Novo Congresso. UOL, São Paulo, 8 out. 2018. Disponível em: https://noticias.uol.com.br/politica/eleicoes/2018/noticias/2018/10/08/mulheres-sao-15-do-novo-congresso-mas-indice-ainda-e-baixo.htm. Acesso em: 12 set. 2019.

MOREIRA, Adilson José. O que é discriminação? Belo Horizonte: Letramento, 2017.

NIGRO, Raquel. A virada linguístico-pragmática e o pós-positivismo. Direito Estado e Sociedade. Revista do Departamento de Direito da PUC-Rio, Rio de Janeiro, n. 34, jan./jun. 2009. 
NOGUEIRA, Oracy. Preconceito racial de marca e preconceito racial de origem: Sugestão de um quadro de referência para a interpretação do material sobre relações raciais no Brasil. Tempo Social, revista de sociologia da USP, São Paulo, v. 19, n. 1, 2007.

ORDENAÇÕES FILIPINAS. Livro V. Título XXXVI: Das penas pecuniárias dos que matam, ferem, ou tiram arma na Corte. Disponível em: http://www1.ci.uc.pt/ihti/proj/filipinas/15ind.htm. Acesso em: 12 set. 2019.

REALE, Miguel. Teoria Tridimensional do Direito. 5. ed. São Paulo: Saraiva, 2003.

SILVA, Nina. O racismo também é uma burrice econômica. Revista Época, 19 dez. 2018. Disponível em: https://epoca.globo.com/o-racismo-tambem-uma-burrice-economica-23313636. Acesso em: 13 set. 2019.

SOUTHEY, Robert. História do Brasil. São Paulo: Melhoramentos, 1977.

SOUZA, Neusa Santos. Tornar-se negro: as vicissitudes da identidade do negro brasileiro em ascenção social. Rio de Janeiro: Edições Graal, 1983.

TADEI, Emanuel Mariano. A Mestiçagem Enquanto um Dispositivo de Poder e a Constituição de Nossa Identidade Nacional. Psicologia, Ciência e Profissão, Distrito Federal: Conselho Federal de Psicologia, 2002.

TERTO, Amauri. Apenas 3\% das bonecas à venda em lojas virtuais no Brasil são negras, aponta estudo. Portal Geledés, 1 out. 2016. Disponível em: https://www.geledes.org.br/apenas-3-das-bonecas-venda-em-lojas-virtuais-no-brasil-sao-negras-aponta-estudo/. Acesso em: 13 set. 2019.

THE GUARDIAN. A Rainha do Carnaval considerada 'negra demais'. Publicado pelo canal do Youtube The Guardian. Disponível em: https://www.youtube.com/watch?v=S0ODz9aIQ_k. Acesso em: 13 set. 2019.

VENOSA, Silvio de Salvo. Direito civil: parte geral. São Paulo: Atlas, 2011. 
